\title{
Melanogenesis-Promoting Effects of Rhynchosia nulubilis and Rhynchosia volubilis Ethanol Extracts in Melan-a Cells
}

\author{
Seong Hee Hong', Mi Ja Sim² and Young Chul Kim ${ }^{3}$ \\ ${ }^{1}$ Department of Beauty Design, Sunlin University, Pohang, Korea \\ ${ }^{2}$ Department of Health \& Beauty Science, Gyeongbuk Provincial College, Yecheon, Korea \\ ${ }^{3}$ Department of Public Health, Keimyung University, Daegu, Korea
}

(Received February 1, 2016; Revised February 25, 2016; Accepted February 29, 2016)

\begin{abstract}
We evaluated the antioxidant activity and melanogenic effects of black soybean ethanol extracts, including Rhynchosia nulubilis bean ethanol extract (RNBEE), $R$. nulubilis leaf ethanol extract (RNLEE), $R$. volubilis bean ethanol extract (RVBEE), and $R$. volubilis leaf ethanol extract (RVLEE). The total polyphenol contents of RNBEE, RNLEE, RVBEE, and RVLEE were 16.0, 57.7, 365.9, and $260.1 \mathrm{mg} / \mathrm{g}$, respectively. The total flavonoid contents of RNBEE, RNLEE, RVBEE, and RVLEE were 40.4, 91.7, 84.7, and 216.5 $\mathrm{mg} / \mathrm{g}$, respectively. The electron-donating abilities of RNBEE, RNLEE, RVBEE, and RVLEE at 1,000 $\mu \mathrm{g} /$ $\mathrm{mL}$ were $32.4 \%, 12.7 \%, 83.5 \%$, and $84.5 \%$, respectively. RNBEE, RNLEE, RVBEE, and RVLEE at $50 \mu \mathrm{g} /$ $\mathrm{mL}$ significantly increased $(p<0.01)$ melanin contents by $30.4 \%, 32.1 \%, 35.5 \%$, and $37.4 \%$, respectively, compared to that of the control. RNBEE, RNLEE, RVBEE, and RVLEE at $50 \mu \mathrm{g} / \mathrm{mL}$ significantly increased $(p<0.01)$ intracellular tyrosinase activity by $18.4 \%, 21.8 \%, 21.5 \%$, and $21.1 \%$, respectively, compared to that of the control. These results demonstrated that black soybean ethanol extracts promote melanogenesis in melan-a cells. Among the black soybean ethanol extracts, $R$. volubilis was found to be more effective than $R$. nulubilis, and leaf extract was found to be more effective than bean extract. The potential mechanism underlying the hyperpigmentation effects of black soybeans is the promotion of tyrosinase activity.
\end{abstract}

Key words: Antioxidant activity, Black soybean ethanol extracts, Melan-a cells, Melanogenesis, Tyrosinase activity

\section{INTRODUCTION}

Graying of hair or canities occurs in all individuals regardless of sex or race and has a positive correlation with chronological aging (1). Recently, premature canities has been increasingly observed in young individuals. Canities is a consequence of decreased melanin synthesis, which leads to the impairment of hair follicle function, but can also be triggered by numerous other intrinsic factors including general metabolism and nutritional status, hair-cycle-dependent changes, variable hormone-responsiveness, genetic defects,

Correspondence to: Young Chul Kim, Department of Public Health, Keimyung University, 1095 Dalgubeol-daero, Daegu 42601, Korea

E-mail: yckim@kmu.ac.kr

This is an Open-Access article distributed under the terms of the Creative Commons Attribution Non-Commercial License (http:// creativecommons.org/licenses/by-nc/3.0) which permits unrestricted non-commercial use, distribution, and reproduction in any medium, provided the original work is properly cited. and age-associated changes (2).

Melanocytes produce the pigment melanin that governs hair color. Within the basal portion of hair follicles, the hair matrix, composed of keratinocytes and melanocytes, grows downward during anagen (3). Analysis of melanocytes during the murine hair cycle revealed that melanocytes could be lost from the hair bulb via apoptosis during hair follicle involution or catagen (4). Ultimately, this can lead to exhaustion of the melanocyte stem cell pool in the bulge region of the hair follicle (5). Two types of melanin are produced by melanocytes: yellow-red pheomelanins and brown-black eumelanins (6). However, there has been no conclusive proof thus far that any of the above-mentioned melanocyte functions are relevant to common graying. Therefore, whether or not apoptosis occurs in aging hair follicle melanocytes and its underlying causes remain unclear (7).

Melanin synthesis is mainly regulated by the tyrosinase. Hair graying results from reduction in tyrosinase activity of hair bulbar melanocytes due to the cytotoxic oxidative nature of melanin biosynthesis, suboptimal melanocyte cortical 
keratinocyte interactions, and defective migration of melanocytes from a reservoir in the upper outer root sheath to the pigment-permitting microenvironment close to the dermal papilla of the hair bulb $(1,8)$.

For more than 100 years, paraphenylenediamine (PPD) and other related members of the aromatic amine family have been the main agents used in permanent hair dyes accounting for more than two-thirds of the commercially manufactured hair dyes (9). PPD causes contact dermatitis in susceptible individuals, but when ingested, causes acute angioedema of face and neck, rhabdomyolysis, and acute renal failure $(10,11)$. Therefore, there is a continued need for alternative methods that can inhibit hair graying using materials that increase tyrosinase activity and melanin synthesis with a less toxic effect on melanocytes.

Soybean (Glycine maxim L. Merrill) seed coats have various colors including yellow, red, green, and black (12). The SoRiTae (G. maxim) and Yakong (Rhynchosia nulubilis and $R$. volubilis) are examples of black soybean and black soybean can be further classified into those with yellow or green cotyledon according to cotyledon color (13). SoRiTae (G. maxim) has a yellow cotyledon and Yakong (R. nulubilis and $R$. volubilis) has a green cotyledon.

$R$. volubilis, a less famous species, has smaller bean than $R$. nulubilis. Yoshida et al. (14) reported that soybean cultivars with black seed coats contain anthocyanins, cyanidin3-glucoside being the dominant component. In addition, black soybeans are superior inhibitors of low-density lipoprotein oxidation compared to yellow soybeans (15). The ferric reducing antioxidant power, free radical-scavenging effect, and total phenolic contents of black soybeans are comparatively higher than those in yellow soybeans (16-18). Lee et al. (19) reported that yellow soybeans (G. maxim) markedly increased melanogenesis by increasing tyrosinase activity. However, the ability of black soybeans (G. maxim) to inhibit tyrosinase activity was also reported (20).

This study was conducted to evaluate the antioxidant activity of $R$. nulubilis ethanol extract (RNEE) and $R$. volubilis ethanol extract (RVEE) and their melanogenic effects on melanin synthesis and tyrosinase activity in melan-a cells.

\section{MATERIALS AND METHODS}

Reagents and apparatus. Dimethyl sulfoxide (DMSO), 2,6-di-tert-butylate hydroxytoluene (BHT), 3,4-dihydroxyL-phenyl-alanine (L-DOPA), 1,1-diphenyl-2-picryl hydrazyl (DPPH), 3-isobutyl-1-methylxanthine (IBMX), tannic acid, L-tyrosine, Folin-Ciocalteu's phenol reagent, 3-(4,5-dimethylthiazol-2-yl)-2,5-diphenyl-tetrazolium bromide (MTT) and 12-o-tetradecanoyl-phorbol-13-acetate (TPA) were obtained from Sigma-Aldrich (St. Louis, MO, USA). Dulbecco's modified Eagle's medium (DMEM), Roswell Park Memorial Institute (RPMI)-1640 medium, fetal bovine serum (FBS) and penicillin/streptomycin mixture $(\mathrm{P} / \mathrm{S})$ were obtained from Lonza (Cascade, MD, USA). Inverted microscope (CKX41, Olympus, Tokyo, Japan) was used to observe cell growth and $\mathrm{CO}_{2}$ incubator (MCO-17AC, Sanyo electric, Osaka, Japan) was used for cell culture.

Preparation of RNEE and RVEE. The beans and leaves of $R$. nulubilis were collected from Yeacheon, Kyungbook and those of $R$. volubilis were collected from Gotjawal, Jeju Iland. Pulverized samples $(50 \mathrm{~g})$ were put into a flask and extracted thrice with $500 \mathrm{~mL}$ of $80 \%$ ethanol for $24 \mathrm{hr}$ each at $25^{\circ} \mathrm{C}$. The extract was filtered through filter paper and concentrated using rotary vacuum evaporator followed by lyophilization. The yield of the leaf and bean extracts of $R$. nulubilis were $16.8 \%$ and $10.1 \%$, respectively, while those of $R$. volubilis were $9.8 \%$ and $11.0 \%$, respectively.

Total polyphenol content. Total polyphenol contents of RNEE and RVEE were measured using the Folin and Denis assay (21). RNEE and RVEE were dissolved in $1 \mathrm{~mL}$ distilled water and placed in test tubes. Folin-reagent $(1 \mathrm{~mL})$ was added and the tubes were allowed to stand for $3 \mathrm{~min}$. Following addition of $1 \mathrm{~mL}$ of $10 \% \mathrm{Na}_{2} \mathrm{CO}_{3}$, the mixture was shaken vigorously and allowed to stand for $60 \mathrm{~min}$. The absorbance was measured at $725 \mathrm{~nm}$ and the polyphenol content was quantified using a standard curve prepared using tannic acid.

Total flavonoid content. Total flavonoid contents of RNEE and RVEE were measured using method of Davies et al. (22) with modification. Samples of extracts $(100 \mu \mathrm{L}$ each of RNEE or RVEE) were mixed with $1 \mathrm{~mL}$ of di-ethylene glycol reagent and $100 \mu \mathrm{L}$ of $1 \mathrm{~N} \mathrm{NaOH}$ in test tubes. The mixture was shaken vigorously and reacted at $37^{\circ} \mathrm{C}$ for $60 \mathrm{~min}$ before measuring the absorbance at $420 \mathrm{~nm}$. The standard curve was prepared using rutin.

Electron-donating ability. DPPH radical scavenging effect was evaluated according to the method of Blois (23). RNEE and RVEE were dissolved in distilled water to a range of final concentrations $(100,500$, and $1000 \mu \mathrm{g} / \mathrm{mL})$ each. Test agent solution $(1 \mathrm{~mL})$ was placed in each test tube, followed by the addition of $4 \mathrm{~mL}$ of $4 \times 10^{-4} \mathrm{M} \mathrm{DPPH}$. The mixture was shaken vigorously and then left for $10 \mathrm{~s}$ at $60^{\circ} \mathrm{C}$ before measuring the absorbance at $525 \mathrm{~nm}$. BHT was used as the positive control.

Cell culture. The melan-a cells (passages 30-37) used in this study were obtained from Dr. Dorothy Bennett (St. George's Hospital, UK). These highly pigmented and immortalized cells were derived from C57BL/6 mice. Cells were grown in RPMI-1640 medium, supplemented with 10\% FBS, $1 \% \mathrm{P} / \mathrm{S}$, and $200 \mathrm{nM}$ TPA at $37^{\circ} \mathrm{C}$ and $10 \% \mathrm{CO}_{2}$ in an incubator for $72 \mathrm{hr}$. 
MTT assay. Cell viability was assessed by the MTT assay. The melan-a cells were seeded in a 96-well plate $\left(0.5 \times 10^{4}\right.$ cells/well $)$ and grown in the incubator at $37^{\circ} \mathrm{C}$ and $10 \% \mathrm{CO}_{2}$ for $24 \mathrm{hr}$. Aliquots $(200 \mu \mathrm{L})$ of RNEE and RVEE, diluted with RPMI-1640 medium to a range of concentrations $(25,50,100$, and $200 \mu \mathrm{g} / \mathrm{mL})$, were added to the wells and the cells were grown in the incubator at $37^{\circ} \mathrm{C}$ and $10 \% \mathrm{CO}_{2}$ for $48 \mathrm{hr}$. Cells were then placed in a medium containing $0.5 \mu \mathrm{g} / \mathrm{mL}$ MTT and grown in the incubator at $37^{\circ} \mathrm{C}$ and $10 \% \mathrm{CO}_{2}$ for $3 \mathrm{hr}$. Following centrifugation of the plate at $200 \times \mathrm{g}$ for $10 \mathrm{~min}$, the cells settled and the medium was removed. DMSO $(200 \mu \mathrm{L})$ was added to each well and the cells were resuspended for $15 \mathrm{~min}$ in a plate-shaker. Absorbance was measured at $540 \mathrm{~nm}$ using a plate reader (680, Bio-Rad, Tokyo, Japan).

Morphological observation of melan-a cells. Melana cells were treated with increasing concentrations of RNEE or RVEE $(10,50,100$, and $200 \mu \mathrm{g} / \mathrm{mL})$ to observe any effect on their morphology, and grown in the incubator at $37^{\circ} \mathrm{C}$ and $10 \% \mathrm{CO}_{2}$ for $48 \mathrm{hr}$. Following incubation, the medium was changed and the cells were observed under an inverted microscope.

Melanin assay. The melan-a cells were distributed in a 48 -well plate $\left(2 \times 10^{4}\right.$ cells/well $)$ and grown in the incubator at $37^{\circ} \mathrm{C}$ and $10 \% \mathrm{CO}_{2}$ for $24 \mathrm{hr}$. Following incubation, $500 \mu \mathrm{L}$ of RNEE and RVEE diluted with RPMI-1640 medium to a range of concentrations $(25,50,100$, and $200 \mu \mathrm{g} /$ $\mathrm{mL}$ ) were added to the wells and the cells were grown in the incubator at $37^{\circ} \mathrm{C}$ and $10 \% \mathrm{CO}_{2}$ for $72 \mathrm{hr}$, and then washed. The same treatment was repeated once more. Next, melanin was dissolved in $1 \mathrm{~N} \mathrm{NaOH}$, and the absorbance was measured at $490 \mathrm{~nm}$ using a plate reader.

Intracellular tyrosinase activity assay. The melan-a cells were distributed in a $60-\mathrm{mm}$ cell culture dish $\left(4 \times 10^{5}\right.$ cells/well), and grown in the incubator at $37^{\circ} \mathrm{C}$ and $10 \%$ $\mathrm{CO}_{2}$ for $24 \mathrm{hr}$. RNEE and RVEE $(5 \mathrm{~mL})$ were diluted with RPMI-1640 medium to a range of concentrations $(25,50$, 100 , and $200 \mu \mathrm{g} / \mathrm{mL}$ ) and added to the dish. Cells were grown in the incubator at $37^{\circ} \mathrm{C}$ and $10 \% \mathrm{CO}_{2}$ for $48 \mathrm{hr}$. The cells were washed with phosphate-buffered saline (PBS), detached with $200 \mu \mathrm{L}$ of $1 \%$ Triton X-100, transferred to Eppendorf tubes, subjected to extraction on ice with agitation six times every $10 \mathrm{~min}$, and then centrifuged at $4^{\circ} \mathrm{C}$ at $18,000 \times \mathrm{g}$ for $20 \mathrm{~min}$. Following centrifugation, $100 \mu \mathrm{L}$ of $0.2 \% \mathrm{~L}$-DOPA was added and the mixture was placed in the incubator at $37^{\circ} \mathrm{C}$ and $10 \% \mathrm{CO}_{2}$ for $1 \mathrm{hr}$, and absorbance was measured at $490 \mathrm{~nm}$ using a plate reader.

Statistical analysis. Statistical analysis was performed using SPSS 21.0 for Windows (IBM, Armonk, NY, USA). The difference between two groups was analyzed by Stu- dent's $t$-test. $P$ values $<0.05$ were considered to be statistically significant.

\section{RESULTS}

Antioxidant activity of the black soybean extracts. The total polyphenol contents of RNBEE, RNLEE, RVBEE, and RVLEE were $16.0,57.7,365.9$, and $260.1 \mathrm{mg} / \mathrm{g}$, respectively, according to the standard curve obtained using tannic acid (Fig. 1). The total flavonoid contents of RNBEE, RNLEE, RVBEE, and RVLEE were 40.4, 91.7, 84.7, and $216.5 \mathrm{mg} / \mathrm{g}$, respectively, according to the standard curve constructed linear using rutin (Fig. 1). Electron-donating

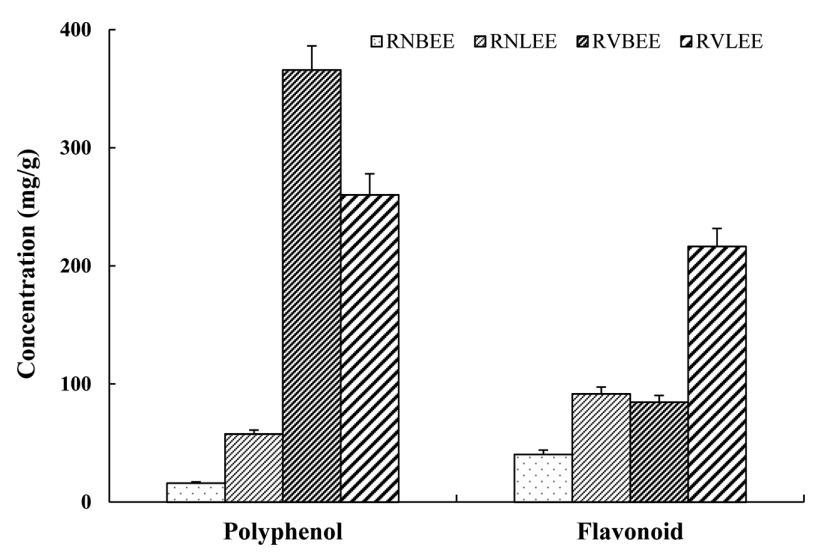

Fig. 1. Total polyphenol and flavonoid contents of RNBEE, RNLEE, RVBEE, and RVLEE. RNBEE: Rhynchosia nulubilis bean ethanol extract, RNLEE: Rhynchosia nulubilis leaf ethanol extract, RVBEE: Rhynchosia volubilis bean ethanol extract, RVLEE: Rhynchosia volubilis leaf ethanol extract. Values are the mean \pm SD of three independent measurements.

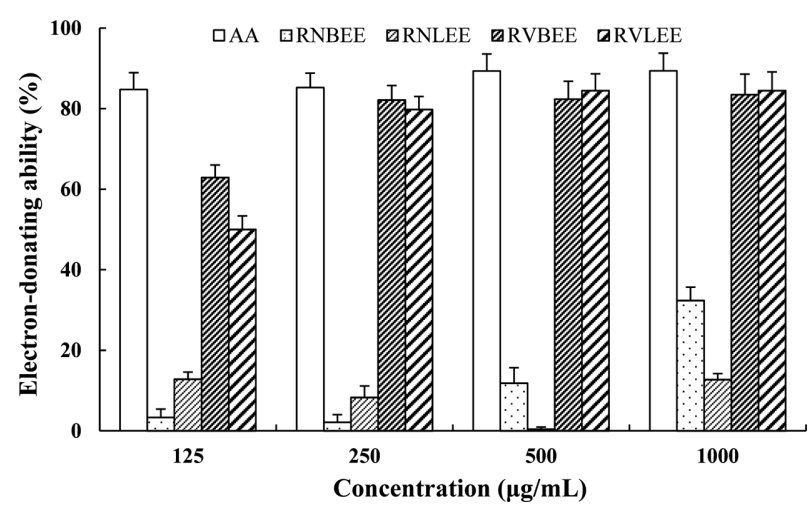

Fig. 2. Electron-donating ability of RNBEE, RNLEE, RVBEE, and RVLEE. Each substance was evaluated for its ability to donate electrons to the free radical DPPH. AA: Ascorbic acid, RNBEE: Rhynchosia nulubilis bean ethanol extract, RNLEE: Rhynchosia nulubilis leaf ethanol extract, RVBEE: Rhynchosia volubilis bean ethanol extract, RVLEE: Rhynchosia volubilis leaf ethanol extract. Values are the mean \pm SD of three independent measurements. 


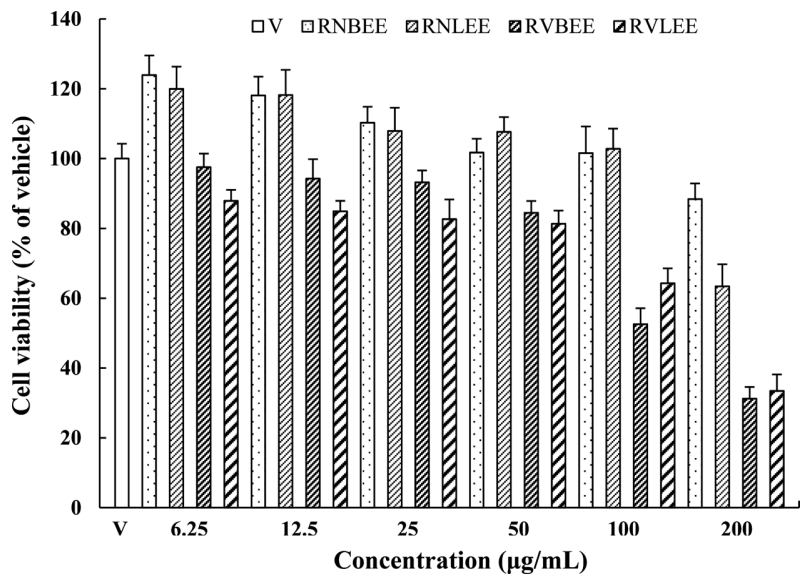

Fig. 3. Effect of RNBEE, RNLEE, RVBEE, and RVLEE on viability of melan-a cells. Viability of melan-a cells treated with test materials $(0 \sim 200 \mu \mathrm{g} / \mathrm{mL})$ for $48 \mathrm{hr}$ was analyzed by MTT assay. V: vehicle, RNBEE: Rhynchosia nulubilis bean ethanol extract, RNLEE: Rhynchosia nulubilis leaf ethanol extract, RVBEE: Rhynchosia volubilis bean ethanol extract, RVLEE: Rhynchosia volubilis leaf ethanol extract. Values are the mean \pm SD of three independent measurements. abilities of RNBEE, RNLEE, RVBEE, and RVLEE at $1,000 \mu \mathrm{g} / \mathrm{mL}$ were $32.4 \%, 12.7 \%, 83.5 \%$, and $84.5 \%$, respectively (Fig. 2). These values were lower than that of ascorbic acid $(94.5 \%)$ at the same concentration.

Effects of the black soybean extracts on melan-a cell viability. The MTT assay was used to determine the maximum permissible level (MPL) of RNEE and RVEE in melan-a cells. RNBEE showed the viability of melan-a cells above $80 \%$ at concentrations between 6.25 and $200 \mu \mathrm{g} / \mathrm{mL}$, compared to the vehicle (Fig. 3). RNLEE showed the cell viability above $80 \%$ at concentrations between 6.25 and $100 \mu \mathrm{g} / \mathrm{mL}$; however, it decreased the cell viability by $36.6 \%$ at $200 \mu \mathrm{g} / \mathrm{mL}$. RVBEE and RVLEE at the concentration of $50 \mu \mathrm{g} / \mathrm{mL}$ showed the viability above $80 \%$. However, cell viability at $100 \mu \mathrm{g} / \mathrm{mL}$ reduced by $47.4 \%$ and $35.7 \%$, respectively. The MPL for RNBEE, RNLEE, RVBEE, and RVLEE in melan-a cells was 200, 100, 50, and $50 \mu \mathrm{g} / \mathrm{mL}$, respectively. IBMX showed the cell viability above $80 \%$ at concentrations of 6.25 and $12.5 \mu \mathrm{g} / \mathrm{mL}$; however, it decreased the cell viability by $25.8 \%$ at $25 \mu \mathrm{g} / \mathrm{mL}$, showing the MPL
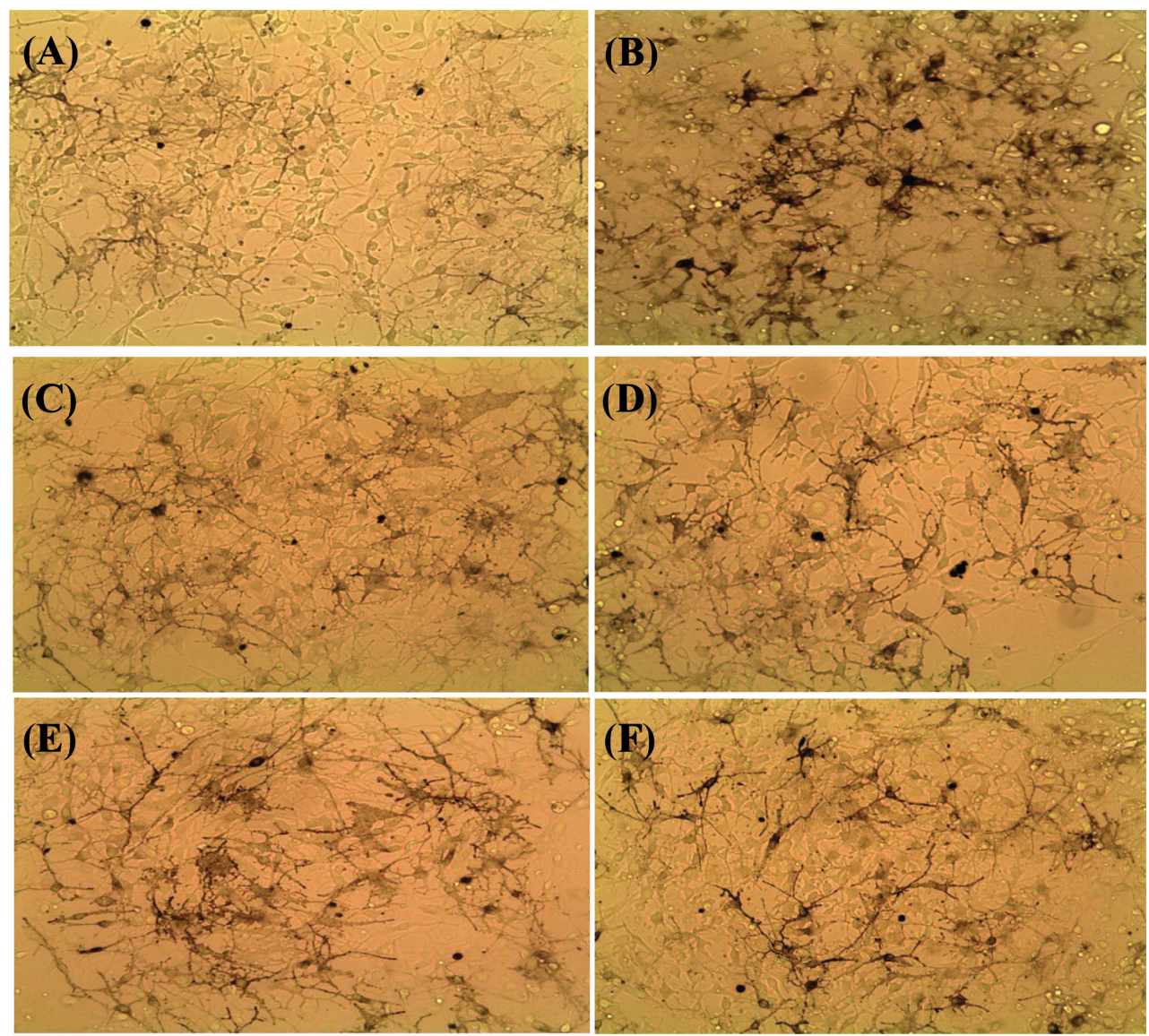

Fig. 4. Morphological changes of melan-a cells treated with RNBEE, RNLEE, RVBEE, and RVLEE. Morphological changes of melan-a cells treated with $12.5 \mu \mathrm{g} / \mathrm{mL} \mathrm{IBMX} \mathrm{(B),} 50 \mu \mathrm{g} / \mathrm{mL}$ RNBEE (C), $50 \mu \mathrm{g} / \mathrm{mL}$ RNLEE (D), $50 \mu \mathrm{g} / \mathrm{mL}$ RVBEE (E), and $50 \mu \mathrm{g} / \mathrm{mL}$ RVLEE (F) for $48 \mathrm{hr}$ were compared to those of untreated control (A). $200 \times$ magnification. 


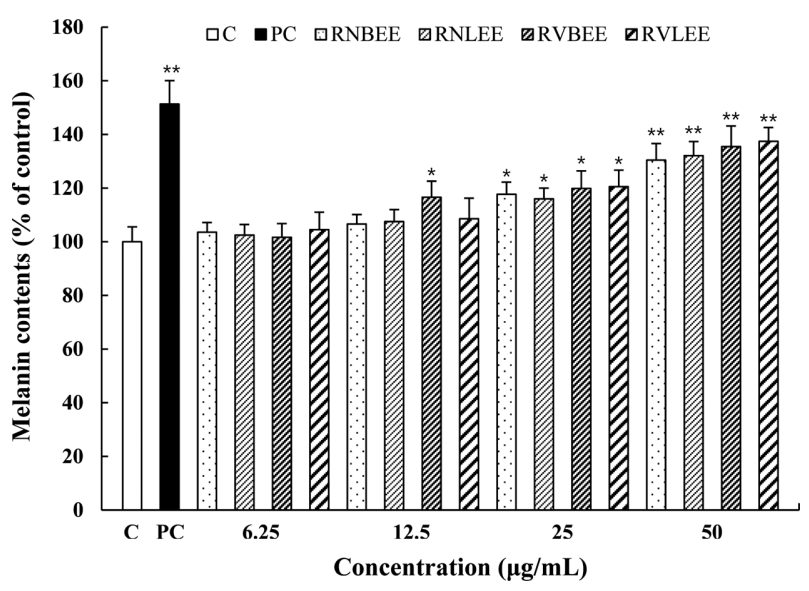

Fig. 5. Melanogenic effect of RNBEE, RNLEE, RVBEE, and RVLEE on melan-a cells. Melanin production in the cells treated with test materials $(6.25 \sim 50 \mu \mathrm{g} / \mathrm{mL})$ for $72 \mathrm{hr}$ was measured by ELISA. C: control, PC: $12.5 \mu \mathrm{g} / \mathrm{mL}$ IBMX, RNBEE: Rhynchosia nulubilis bean ethanol extract, RNLEE: Rhynchosia nulubilis leaf ethanol extract, RVBEE: Rhynchosia volubilis bean ethanol extract, RVLEE: Rhynchosia volubilis leaf ethanol extract. Values are the mean \pm SD of three independent measurements. The values with an asterisk are significantly different from the control group by Student's $t$-test $\left({ }^{*} p<0.05,{ }^{* *} p<0.01\right)$.

of $12.5 \mu \mathrm{g} / \mathrm{mL}$ (data not shown). IBMX $(12.5 \mu \mathrm{g} / \mathrm{mL})$, and RNBEE, RNLEE, RVBEE, and RVLEE at the concentration of $50 \mu \mathrm{g} / \mathrm{mL}$ resulted in increased accumulation of melanin and melanocyte dendrites in melan-a cells compared to those observed in untreated control (Fig. 4).

Effects of the black soybean extracts on melanin synthesis. In comparison with the control group, the melanin contents of RNBEE, RNLEE, RVBEE, and RVLEEtreated groups significantly increased $(p<0.01)$ at $50 \mu \mathrm{g} /$ $\mathrm{mL}$ by $30.4 \%, 32.1 \%, 35.5 \%$, and $37.4 \%$, respectively (Fig. 5). IBMX (PC) at $12.5 \mu \mathrm{g} / \mathrm{mL}$ also significantly $(p<0.01)$ increased the melanin contents by $51.3 \%$, compared to the control.

Effects of the black soybean extracts on tyrosinase activity. In comparison with the control treatment, treatment with RNBEE, RNLEE, RVBEE, and RVLEE at $50 \mu \mathrm{g} /$ $\mathrm{mL}$ significantly increased $(p<0.01)$ intracellular tyrosinase activities by $18.4 \%, 21.8 \%, 21.5 \%$, and $21.1 \%$, respectively (Fig. 6). IBMX at $12.5 \mu \mathrm{g} / \mathrm{mL}$ also significantly increased the tyrosinase activity by $67.4 \%(p<0.001)$.

\section{DISCUSSION}

A form of transient "canities" occurs at the end of every hair growth cycle. Small numbers of dendritic melanocytes can be detected in the retreating epithelial strand of catagen undergoing active resorption via apoptosis (2). "Free radi-

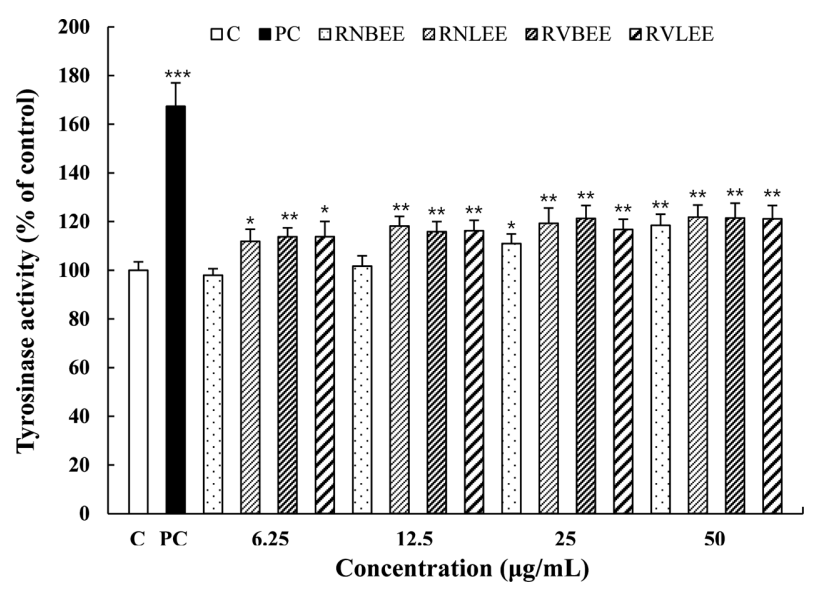

Fig. 6. Effect of RNBEE, RNLEE, RVBEE, and RVLEE on intracellular tyrosinase activity in melan-a cells. Intracellular tyrosinase activity in the cells treated with test materials $(6.25 \sim 50 \mu \mathrm{g} / \mathrm{mL})$ for $48 \mathrm{hr}$ was measured by ELISA. C: control, PC: $12.5 \mu \mathrm{g} / \mathrm{mL}$ IBMX, RNBEE: Rhynchosia nulubilis bean ethanol extract, RNLEE: Rhynchosia nulubilis leaf ethanol extract, RVBEE: Rhynchosia volubilis bean ethanol extract, RVLEE: Rhynchosia volubilis leaf ethanol extract. Values are the mean \pm SD of three independent measurements. The values with an asterisk are significantly different from the control group by Student's $t$-test $\left({ }^{*} p<0.05,{ }^{* *} p\right.$ $\left.<0.01,{ }^{* * *} p<0.001\right)$.

cal" theory of aging is by far the most popular theory for skin aging and can also be easily verified in vitro. Based on the theory, the extraordinary melanogenic activity of a limited number of pigmented bulbar melanocytes, in some hair follicles, can most likely generate large amounts of reactive oxygen species (ROS) via the oxidation of tyrosine and DOPA to melanin. It is most likely that the remarkably high levels of follicular melanogenesis would need to be regulated by an efficient antioxidant system. If not adequately removed, accumulation of these ROS would induce nuclear and mitochondrial DNA damages, ultimately resulting in the accumulation of mutations and induction of oxidative stress (8). Therefore, more studies on antioxidant and electron transfer systems are needed for further progress in this field.

Total polyphenol and flavonoid contents have been widely used either to assess the free radical-scavenging activity or to study the antioxidant activity of plant extracts. Total polyphenol and flavonoid contents and electron-donating ability of RNBEE, RNLEE, RVBEE, and RVLEE were determined to assess the anti-oxidative capacity. The total polyphenol contents of RNBEE, RNLEE, RVBEE, and RVLEE were 16.0, 57.7, 365.9, and $260.1 \mathrm{mg} / \mathrm{g}$, respectively; the total flavonoid contents of those were 40.4, 91.7, 84.7 , and $216.5 \mathrm{mg} / \mathrm{g}$, respectively, RVEE had higher total polyphenol and flavonoid contents than RNEE. According to Hong et al. (24), the total polyphenol and flavonoid contents of black soybean (R. nulubilis) water extract were 23.0 
and $30.5 \mathrm{mg} / \mathrm{g}$, respectively. Therefore, RNEE and RVEE have a higher antioxidant activity than $R$. nulubilis water extract. In the current study, electron-donating abilities of RNBEE, RNLEE, RVBEE, and RVLEE at $1,000 \mu \mathrm{g} / \mathrm{mL}$ were $32.4 \%, 12.7 \%, 83.5 \%$, and $84.5 \%$, respectively. According to Ralison (25), DPPH radical-scavenging ability of black soybean (G. maxim) at $1,000 \mu \mathrm{g} / \mathrm{mL}$ was $25 \%$. RNBEE, RVBEE and RVLEE have a higher radical-scavenging capacity than black soybean (G. maxim). These results indicate that RNBEE, RNLEE, RVBEE, and RVLEE are valuable natural antioxidants.

Melan-a cells are an immortal cell line of pigmented melanocytes commonly used in the study of melanin biosynthesis (26). In the present study, the effect of RNEE and RVEE on hair graying was evaluated using melan-a cells derived from C57BL/6 mice. Lee et al. (19) reported that melanin contents in melan-a cells significantly increased by $51.2 \%$ after treatment with $12.5 \mu \mathrm{g} / \mathrm{mL}$ of yellow soybean (G. maxim) methanol extract. In the current study, RNBEE, RNLEE, RVBEE, and RVLEE-treated groups showed a dose-dependent increase in melanin levels, although the increase observed was not as prominent as that observed by Lee et al. (19). In addition, RVEE had greater melanogenic effects than RNEE.

Tyrosinase is the rate-limiting enzyme for melanin biosynthesis; therefore, the effect of RNEE and RVEE on intracellular tyrosinase activity was determined. According to Lee et al. (19), yellow soybean (G. maxim) methanol extract increased the intracellular tyrosinase activity in a dosedependent manner. In contrast, Lai et al. (27) reported that black soybean (G. maxim) water extract from sprouts grown to $0.5 \mathrm{~cm}$ inhibited the mushroom tyrosinase activity by $40 \%$ at $2,000 \mu \mathrm{g} / \mathrm{mL}$. In the current study, in comparison with the control group, RNBEE, RNLEE, RVBEE, and RVLEE at $50 \mu \mathrm{g} / \mathrm{mL}$ significantly increased intracellular tyrosinase activity $(p<0.01)$.

In conclusion, we verified that RNBEE, RNLEE, RVBEE, and RVLEE promote melanin synthesis by increasing tyrosinase activity. $R$. volubilis is more effective than $R$. nulubilis and the leaf is more effective than the bean. Among these, RVLEE may be the most effective hyperpigmentation agent with lower cytotoxicity than IBMX.

\section{REFERENCES}

1. Tobin, D.J. and Paus, R. (2001) Graying: gerontobiology of the hair follicle pigmentary unit. Exp. Gerontol., 36, 29-54.

2. McDonough, P.H. and Schwartz, R.A. (2012) Premature hair graying. Cutis, 89, 161-165.

3. Nishimura, E.K., Jordan, S.A., Oshima, H., Yoshida, H., Osawa, M., Moriyama, M., Jackson, I.J., Barrandon, Y., Miyachi, Y. and Nishikawa, S. (2002) Dominant role of the niche in melanocyte stem-cell fate determination. Nature, 416, 854860.

4. Paus, R., Müller-Röver, S. and Botchkarev, V.A. (1999) Chro- nobiology of the hair follicle: hunting the "hair cycle clock". J. Investig. Dermatol. Symp. Proc., 4, 338-345.

5. Nishimura, E.K., Granter, S.R. and Fisher, D.E. (2005) Mechanisms of hair graying: incomplete melanocyte stem cell maintenance in the niche. Science, 307, 720-724.

6. Wakamatsu, K. and Ito, S. (2002) Advanced chemical methods in melanin determination. Pigment Cell Res., 15, 174-183.

7. Arck, P.C., Overall, R., Spatz, K., Liezman, C., Handjiski, B., Klapp, B.F., Birch-Machin, M.A. and Peters, E.M. (2006) Towards a "free radical theory of graying": melanocyte apoptosis in the aging human hair follicle is an indicator of oxidative stress induced tissue damage. FASEB J., 20, 1567-1569.

8. Van Neste, D. and Tobin, D.J. (2004) Hair cycle and hair pigmentation: dynamic interactions and changes associated with aging. Micron, 35, 193-200.

9. Warbrick, E.V., Dearman, R.J., Lea, L.J., Basketter, D.A. and Kimber, I. (1999) Local lymph node assay responses to paraphenylenediamine: intra- and inter-laboratory evaluations. $J$. Appl. Toxicol., 19, 255-260.

10. Mathur, A.K., Gupta, B.N., Narang, S., Singh, S., Mathur, N., Singh, A., Shukla, L.J. and Shanker, R. (1990) Biochemical and histopathological changes following dermal exposure to paraphenylene diamine in guinea pigs. J. Appl. Toxicol., 10, 383-386.

11. Ashraf, W., Dawling, S. and Farrow, L.J. (1994) Systemic paraphenylenediamine (PPD) poisoning: a case report and review. Hum. Exp. Toxicol., 13, 167-170.

12. Jeng, T.L., Shih, Y.J., Wu, M.T. and Sung, J.M. (2010) Comparisons of flavonoids and anti-oxidative activities in seed coat, embryonic axis and cotyledon of black soybeans. Food Chem., 123, 1112-1116.

13. Choung, M.G., Baek, I.Y., Kang, S.T., Han, W.Y., Shin, D.C., Moon, H.P. and Kang, K.H. (2001) Isolation and determination of anthocyanins in seed coats of black soybean (Glycine $\max$ (L.) Merr.). J. Agric. Food Chem., 49, 5848-5851.

14. Yoshida, K., Sato, Y., Okuno, R., Kameda, K., Isobe, M. and Kondo, T. (1996) Structural analysis and measurement of anthocyanins from colored seed coats of Vigna, Phaseolus, and Glycine Legumes. Biosci. Biotech. Biochem., 60, 589593.

15. Takahashi, R., Ohmori, R., Kiyose, C., Momiyama, Y., Ohsuzu, F. and Kondo, K. (2005) Antioxidant activities of black and yellow soybeans against low density lipoprotein oxidation. $J$. Agric. Food Chem., 53, 4578-4582.

16. Xu, B.J., Yuan, S.H. and Chang, S.K. (2007) Comparative analyses of phenolic composition, antioxidant capacity, and color of cool season legumes and other selected food legumes. J. Food Sci., 72, S167-S177.

17. Xu, B. and Chang, S.K. (2008) Antioxidant capacity of seed coat, dehulled bean, and whole black soybeans in relation to their distributions of total phenolics, phenolic acids, anthocyanins, and isoflavones. J. Agric. Food Chem., 56, 8365-8373.

18. Kumar, V., Rani, A., Dixit, A.K., Pratap, D. and Bhatnagar, D. (2010) A comparative assessment of total phenolic content, ferric reducing-anti-oxidative power, free radical-scavenging activity, vitamin $\mathrm{C}$ and isoflavones content in soybean with varying seed coat colour. Food Res. Int., 43, 323-328.

19. Lee, J.S., Lee, B.S. and Kim, Y.C. (2013) Promoting effects of soybean methanol extract on the melanogenesis and tyrosi- 
nase activity. J. Invest. Cosmetol., 9, 339-345.

20. Chae, G.Y. and Ha, B.J. (2011) The comparative evaluation of fermented and non-fermented soybean extract on antioxidation and whitening. Toxicol. Res., 27, 205-209.

21. Folin, O. and Denis, W. (1912) On phosphotungstic-phosphomolybdic compounds as color reagents. J. Biol. Chem., 12, 239-243.

22. Davies, R., Massey, R.C. and Mcweeny, D.J. (1980) The catalisis of the $N$-nitrosation of secondary amines by nitrosophenols. Food Chem., 6, 115-122.

23. Blois, M.S. (1958) Antioxidant determinations by the use of a stable free radical. Nature, 181, 1199-1200.

24. Hong, J.Y., Shin, S.R., Kong, H.J., Choi, E.M., Woo, S.C., Lee, M.H. and Yang, K.M. (2014) Antioxidant activity of extracts from soybean and small black bean. Korean J. Food
Preserv., 21, 404-411.

25. Ralison, S.S., Tounkara, F., Karangwa, E., Yong, H.S. and Le, G.W. (2013) In vitro antioxidant activities of protein hydrolysate from germinated black soybean (Glycine max L.). Adv. J. Food Sci. Technol., 5, 453-459.

26. Sheffield, M.V., Yee, H., Dorvault, C.C., Weilbaecher, K.N., Eltoum, I.A., Siegal, G.P., Fisher, D.E. and Chhieng, D.C. (2002) Comparison of five antibodies as markers in the diagnosis of melanoma in cytologic preparations. Am. J. Clin. Pathol., 118, 930-936.

27. Lai, J., Xin, C., Zhao, Y., Feng, B., He, C., Dong, Y., Fang, Y. and Wei, S. (2012) Study of active ingredients in black soybean sprouts and their safety in cosmetic use. Molecules, 17, 11669-11679. 